Cássio Vasconcellos

"Tecidos Urbanos", 2007 


\section{(5) 6}

\section{3.}

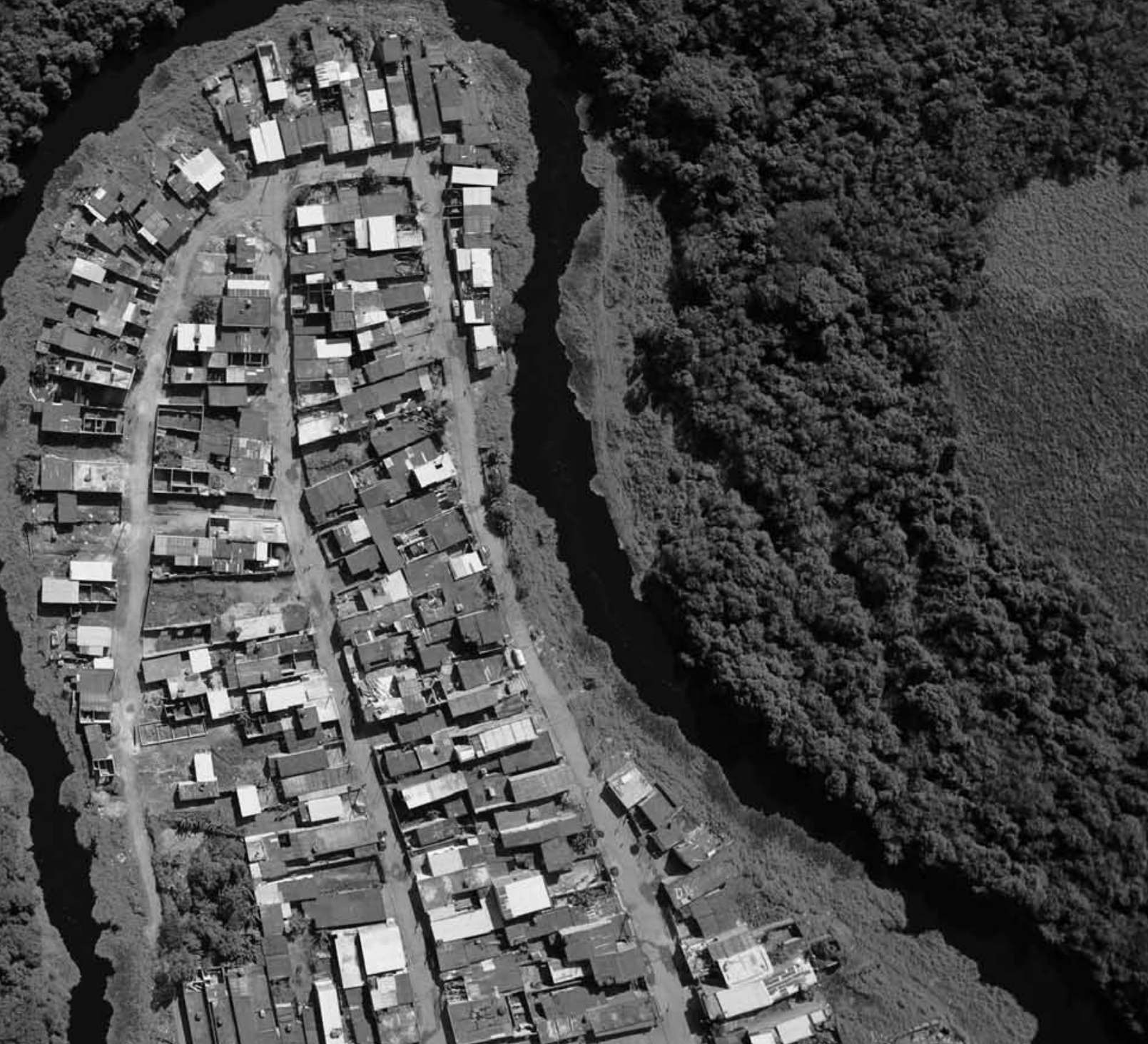

\section{Stinn:}




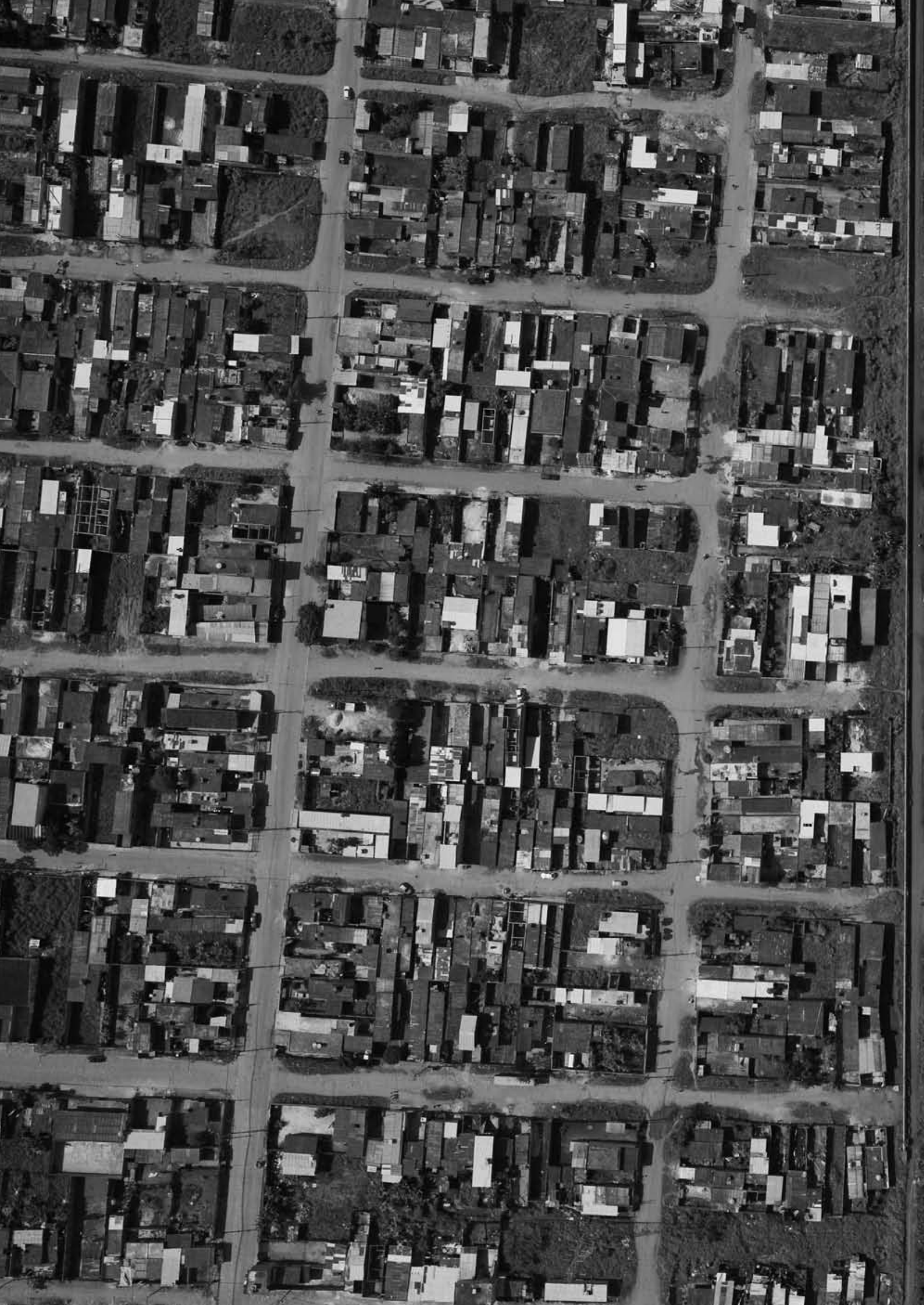




in

$x^{2}-9,5$

$\frac{3}{4}+12$

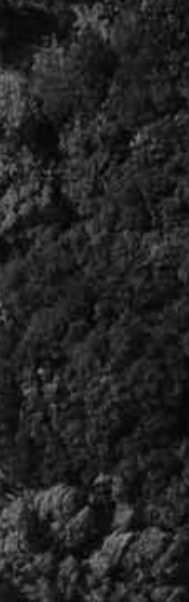

axing nex


(3) sie

n. norese a divares (c)

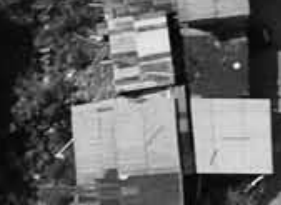
$\frac{1}{4}$ से क करे? xo 알 ,

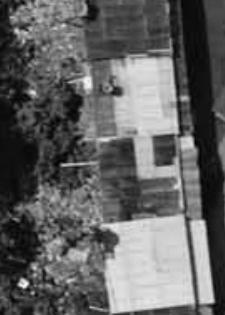
(2) $1 \times 2$ $-121$ 


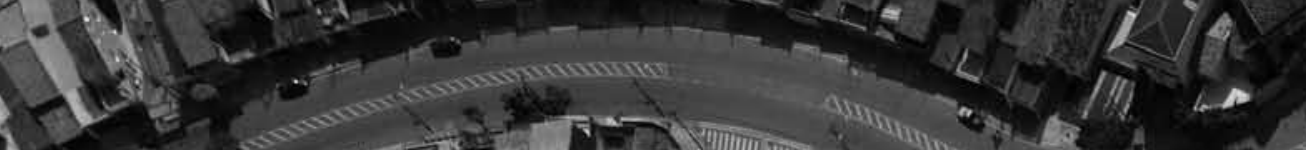






